\title{
Effects of topical $0.2 \%$ Cyclosporine A on corneal neovascularization induced by xenologous amniotic membrane implantation into a corneal stroma micropocket of rats ${ }^{1}$
}

\author{
Juliana F. Milani², Paulo S.M. Barros ${ }^{2 *}$, José L. Guerra ${ }^{3}$ and Dennis E. Brooks ${ }^{4}$
}

\begin{abstract}
Milani J.F., Barros P.S.M., Guerra J.L. \& Brooks D.E. 2008. Effects of topical $0.2 \%$ Cyclosporine $A$ on corneal neovascularization induced by xenologous amniotic membrane implantation into a corneal stroma micropocket of rats. Pesquisa Veterinária Brasileira 28(8):379-386. Laboratório de Investigação em Oftalmologia Comparada, Faculdade de Medicina Veterinária e Zootecnia, Universidade de São Paulo, Av. Prof. Orlando Marques de Paiva 87, São Paulo, SP 05508-900, Brazil. E-mail: pauloeye@usp.br

The objective of the study was to evaluate the topical effects of $0.2 \%$ Cyclosporine A (CsA) on corneal neovascularization of rats following surgical implantation of equine amniotic membrane into a corneal stroma micropocket. The implantation of xenologous amniotic membrane was performed bilaterally in 90 rats. In the same day of the surgery each right eye started receiving topical CsA twice a day. The left eye received no medication and served as a control. The evaluation of corneal neovascularization was performed by computerized image analysis and histopathological evaluation at 1, 3, 7, 15, 30 and 60 days postoperatively. For the image analysis 10 animals were used per time period, and for the histopathological examination, five animals were used per time period. Image analysis found that corneal neovascularization began on the 3rd postoperative day, reached its peak on the 7th day, and then progressively and rapidly decreased. Statistic analysis indicated that neovascularization of the CsA treated eye on the 7th day was significantly higher than that observed in untreated eyes. On the 30th day, however, this pattern was reversed with the neovascularization observed in the CsA treated eyes declining to the low levels observed on the 3rd day. The degree of neovascularization in the untreated eyes on the 30th day declined to the baseline levels found on day 3 at the 60th day. Histopathological analysis indicated that deposition of collagen in the implanted tissue was completed by the 15th day. Therefore, we concluded that (1) equine amniotic membrane in rat corneal stroma produced an intense neovascularization until the 15th day postoperatively and then regressed, (2) deposition of collagen of the implanted tissue was completed on the 15th day postoperatively, and (3) use of CsA was associated with increase in the corneal neovascularization initially, followed by a quick and intense regression.
\end{abstract}

INDEX TERMS: Amniotic membrane, cyclosporine, cornea, veterinary, ophthalmology.

\footnotetext{
${ }^{1}$ Received on April 24, 2008.

Accepted for publication on August 19, 2008.

2 Laboratório de Investigação em Oftalmologia Comparativa, Faculdade de Medicina Veterinária e Zootecnia (FMVZ), Universidade de São Paulo (USP), Av. Prof. Orlando Marques de Paiva 87, São Paulo, SP 05508-900, Brasil. *Correponding author: pauloeye@usp.br

3 Departamento de Patologia, FMVZ, USP, São Paulo, SP.

${ }^{4}$ Department of Small Animal Clinical Sciences, Section of Comparative Ophthalmology, College of Veterinary Medicine, University of Florida, PO Box 100126, Gainesville, FL 32610, USA.
}

RESUMO.- [Efeitos do uso tópico da Ciclosporina A (CsA) $0,2 \%$ na neovascularização corneal induzida pelo implante de membrana amniótica xenógena em microbolsa no estroma da córnea de ratos.] Este estudo teve como objetivo a avaliação dos efeitos tópicos da Ciclosporina a 0,2\% (CsA) sobre a neovascularização corneana de ratos após implante cirúrgico de membrana amniótica eqüina em microbolsa do estroma corneana. O implante da membrana foi feito bilateralmente em 90 ratos. $O$ tratamento com 
CsA iniciou-se no mesmo dia da cirurgia, nos olhos direitos dos animais, duas vezes ao dia. Os olhos esquerdos não receberam nenhum tratamento e serviram de controle. A avaliação da neovascularização corneana foi feita por análise de imagem computadorizada e por exame histopatológico aos dias 1, 3, 7, 15, 30 e 60 de pós-cirúrgico. Para a análise de imagem foram utilizados 10 animais por período, e para o exame histopatológico, 5 por período. A análise de imagem demonstrou que a neovascularização iniciou-se no $3^{\circ}$ dia pós-cirúrgico, alcançou seu pico no $7^{\circ}$ dia e então regrediu rápida e progressivamente até $060^{\circ}$ dia. A análise estatística indicou que a neovascularização no $7^{\circ}$ dia nos olhos tratados com CsA foi significantemente mais acentuada do que aquela observada nos olhos não tratados. Entretanto, no $30^{\circ}$ dia este fato se reverteu, e a neovascularização observada nos olhos tratados com CsA diminuíra a níveis baixos comparáveis àquela do $3^{\circ}$ dia. Já nos olhos não tratados, o grau de neovascularização somente pôde ser comparado àquele nível básico encontrado no $3^{\circ}$ dia aos 60 dias de pós-operatório. A análise histopatológica demonstrou que a deposição de colágeno no tecido implantado se completou no $15^{\circ}$ dia. Desta maneira, foi possível concluir que (1) a membrana amniótica em estroma corneano de ratos produz intensa neovascularização até o $15^{\circ}$ dia de pósoperatório com posterior regressão, (2) a deposição de colágeno do tecido implantado foi completa ao $15^{\circ}$ dia de pós-operatório, e que (3) o uso de CsA esteve associado com aumento inicial da neovascularização corneana, seguido de rápida e intensa regressão.

TERMOS DE INDEXAÇÃO: Membrana amniótica, ciclosporina, córnea, veterinária, oftalmologia.

\section{INTRODUCTION}

Biologic membranes grafts such as amnion, pericardium, renal capsule, and conjunctiva are being used for the repair of corneal diseases such as deep ulcerative keratitis, descementocele, staphyloma, iris prolapse, or after excision of cornea, sclera or limbal tumors. The problem with such membranes is that they induce varying amounts of neovacularization and/or opacity of the cornea to result in decreased vision of the patient (Hakanson \& Merideth 1986, Barros et al. 1995, Andrade et al. 1999, Godoy et al. 2002).

The angiogenic producing capacity of biologic membranes can vary. A study comparing xenologous amniotic membrane with xenologous pericardium using micropocket implants in rat corneal stroma demostrated that the pericardium induced more corneal neovasculari-zation than amniotic membrane (Safatle et al. 2002). Another study showed that angiogenesis was effectively retarded by cyclosporine in rat models of corneal angiogenesis induced by xenotransplantation and/or by chemical cauterization (Benelli et al. 1997). Many drugs have been used to suppress angiogenesis such as cytokine inhibitors interleukin-1 receptor antagonist (Coxon et al. 2002), FGF inhibitors as rapamycin (Kwon \& Kim 2006), FGF-2 inhibitors as hypericin (Lavie et al. 2005), doxycycline and triancinolone (Riazi-Esfahani et al. 2006), anti-VGEF antibodies as ranibizumab (Lucentis ${ }^{\circledR}$ ) (Heier et al. 2006), pegaptanib (Macugen®) (Macugen Diabetic Retinopathy Group 2006), bevacizumab (Avastin ${ }^{\circledR}$ ) (Manzano et al. 2006, Barros \& Belfort Jr 2007, Hosseini \& Nejabat 2007) or VEGF trap drugs (Liu et al. 2006).

This study evaluated the topical effect of $0.2 \%$ cyclosporine A by histopathological and computerized image analysis on corneal neovascularization of rats with implantation of equine amniotic membrane in a micropocket of corneal stroma.

\section{MATERIALS AND METHODS}

Animals. Ninety female, adult, healthy Wistar rats without any corneal injury with an average weight of $200 \mathrm{~g}$ were used. The animals were kept in appropriate boxes and wood shavings, and fed with ad libitum water and animal feed.

Anesthesia. Animals were anaesthetized by intraperitoneal injection of $0.1 \mathrm{ml} / 100 \mathrm{~g}$ of ketamine chloral hydrate $(50 \mathrm{mg} / \mathrm{ml})$ and xylazine chloral hydrate, associated at the rate of $2: 1$.

Implant of the amniotic membrane. Equine amniotic membrane, stored in $98 \%$ glycerin was used. The implant was hydrated with a solution of sodium chloride $0.9 \%$ for 15 minutes prior to implantation. With the animal anaesthetized and in lateral recumbency, an operating microscope with a number 11 needle without a bevel was used to perform a longitudinal incision about $0.3 \mathrm{~mm}$ from the limbus followed by dissection of the corneal stroma towards the center of the cornea. A microcavity or pocket was formed between the collagen layers up to $3 / 4$ of the cornea radius. Fragments $(1 \mathrm{~mm} \times 1 \mathrm{~mm})$ of amniotic membrane were then inserted inside each micropocket in both eyes. This pocketsurgery has been previously proved not to cause any significant neovascularization alone (Safatle et al. 2002).

Treatment with $\mathbf{0 . 2} \%$ Cyclosporine A (CsA). Right after the implantation of the amniotic membrane in the rat corneas, the treatment with $0.2 \%$ Cyclosporine A (ointment presentation - Optimmune®/Shering-Plough) was initiated twice a day in right eyes only (the left eyes serving as controls).

Filling of the vascular bundle with Nankeen Ink. Animals were deeply anaesthetized on the 1st, 3rd, 7th, 15th, 30th and 60 th day postoperatively (10 animals per period). The animals were catheterized and given intravenous (femoral vein) heparin (500 UI). Five minutes later, the thoracic region skin was incised and the thorax was opened through a mediastinal incision. Animals were then euthanized by exsanguination through an incision in the left ventricle, and a cannula was put in the brachiocephalic trunk to slowly infuse $10 \mathrm{ml}$ of Nankeen Ink (Faber-Castell $($ ) in order to fill the vasculature. The eyes were enucleated and fixed in Formaldehyde 10\%.

Dehydration and diaphanous rendering (Spalthölz Method). After 48 hours, the eyes were washed for one hour in running water, dehydrated in crescent alcoholic solutions $\left(50^{\circ} \mathrm{GL}\right.$, $60^{\circ} \mathrm{GL}, 70^{\circ} \mathrm{GL}, 80^{\circ} \mathrm{GL}, 95^{\circ} \mathrm{GL}$ and $100 \%, 24$ hours in each solution), rendered diaphanous in two passages of 24 hours each of benzol, and preserved in a solution of methyl salicylate and benzyl benzoate (mixed at the rate of 5:3). The corneas were then removed from the eyes, divided into two equal parts, and put between two microscope glass slides fixed by staples (paper staple of grampomol type), in such a way 48 hours later the corneas were totally widened and could be fixed between a microscope glass slide and a microscope covers lip with resinoid. 
Quantifying of corneal neovascularization by computerized image analysis. The neovascularization density in a defined area was used to quantify the neovascularization of the corneas after diaphanous rendering. The area utilized was a rectangle of defined area $(x)$ in the most vascularized region between the limbus and the implant, as close as possible to the limbus. To choose the most

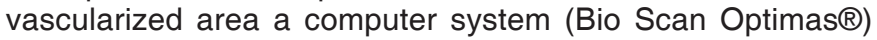
indicated the degrees of vascularization with different colors. The software also gave the area of vascularization inside the rectangle $(y)$, which was different for each sample. The neovascularization density for each sample was obtained by dividing (y) by (x). The rectangular area $(\mathrm{x})$ was kept constant for all samples.

Statistic analysis. Statistic analysis was performed at a $5 \%$ level of significance by means of four comparisons of the neovascularization: analysis of the averages and their standard deviations; analysis of variances with repeated measures; Bonferroni's and Tukey-Kramer's multiple comparisons between the eyes; and Bonferroni's and Tukey-Kramer's multiple comparisons between the periods.
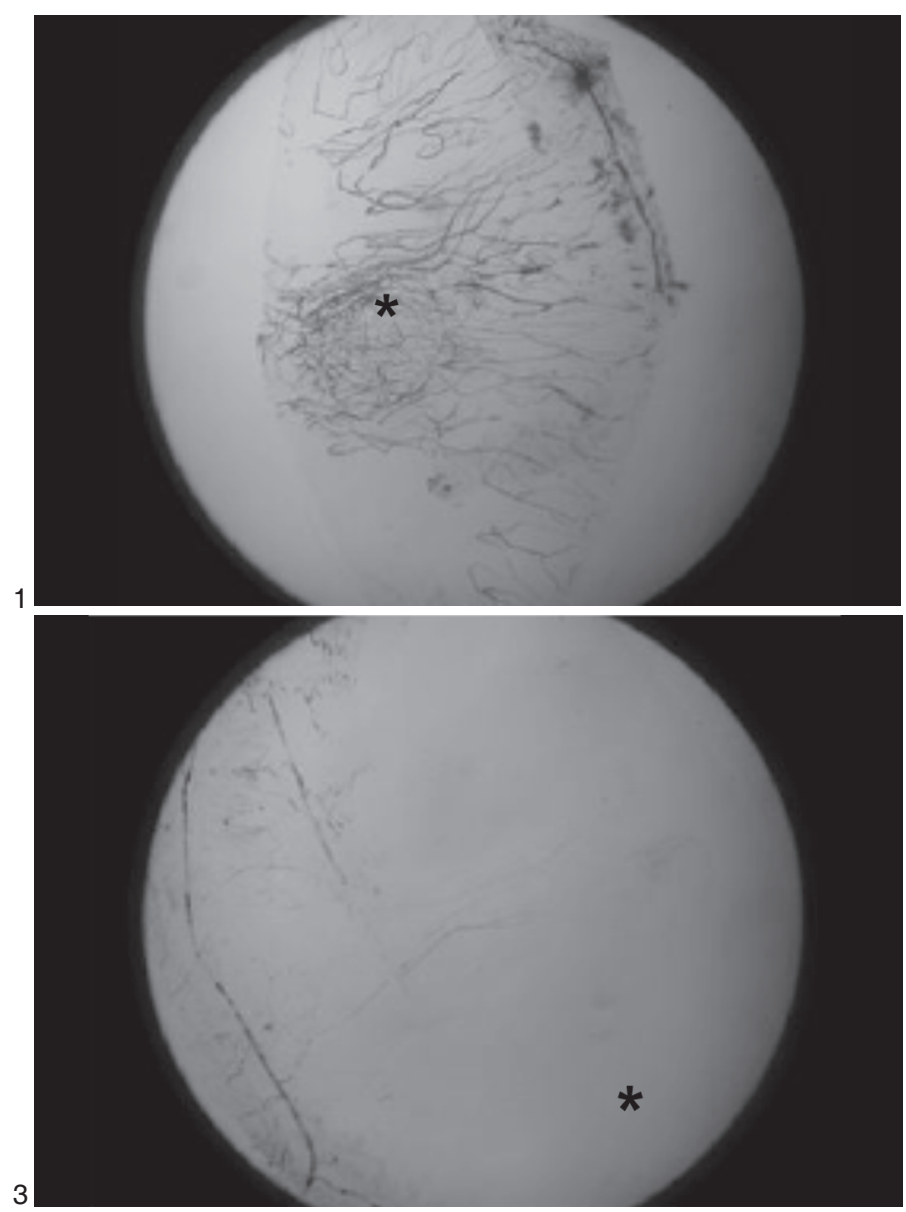

Fig.1. Rat cornea after intravenous injection of Nankeen Ink 15 days after the implantation of amniotic membrane, without treatment. Observe the corneal neovascularization involving the amniotic membrane implant ( $*)$.

Fig.3. Rat cornea after intravenous injection of Nankeen Ink 60 days after the implantation of amniotic membrane, without treatment. Note that the neovascularization is almost absent. ( $*=$ amniotic membrane implant)
Histopathological analysis. We analyzed corneas from the eyes of $1^{\text {st }}, 3^{\text {rd }}, 7^{\text {th }}, 15^{\text {th }}, 30^{\text {th }}$ and $60^{\text {th }}$ days postoperatively (five per period). For this, the eyes were preserved in formaldehyde $10 \%$ for 24 hours. Afterwards the corneas were removed (preserving the cornea-sclera region) and sectioned into four parts. The parts with the implant were dehydrated in alcoholic solutions of crescent concentrations, included in paraffin and sectioned into a microtome (5mm of thickness). Thereafter, the fragments were stained with haematoxylin-eosin (HE) and analyzed under a light microscope.

\section{RESULTS}

\section{Computerized image analysis}

Computer image analysis indicated that there was obvious neovascularization beginning the $3^{\text {rd }}$ day postoperatively, reaching its peak on the $7^{\text {th }}$ day postoperatively, and then decreasing until the $15^{\text {th }}$ day postoperatively (Fig.1, 2). A progressive decrease until
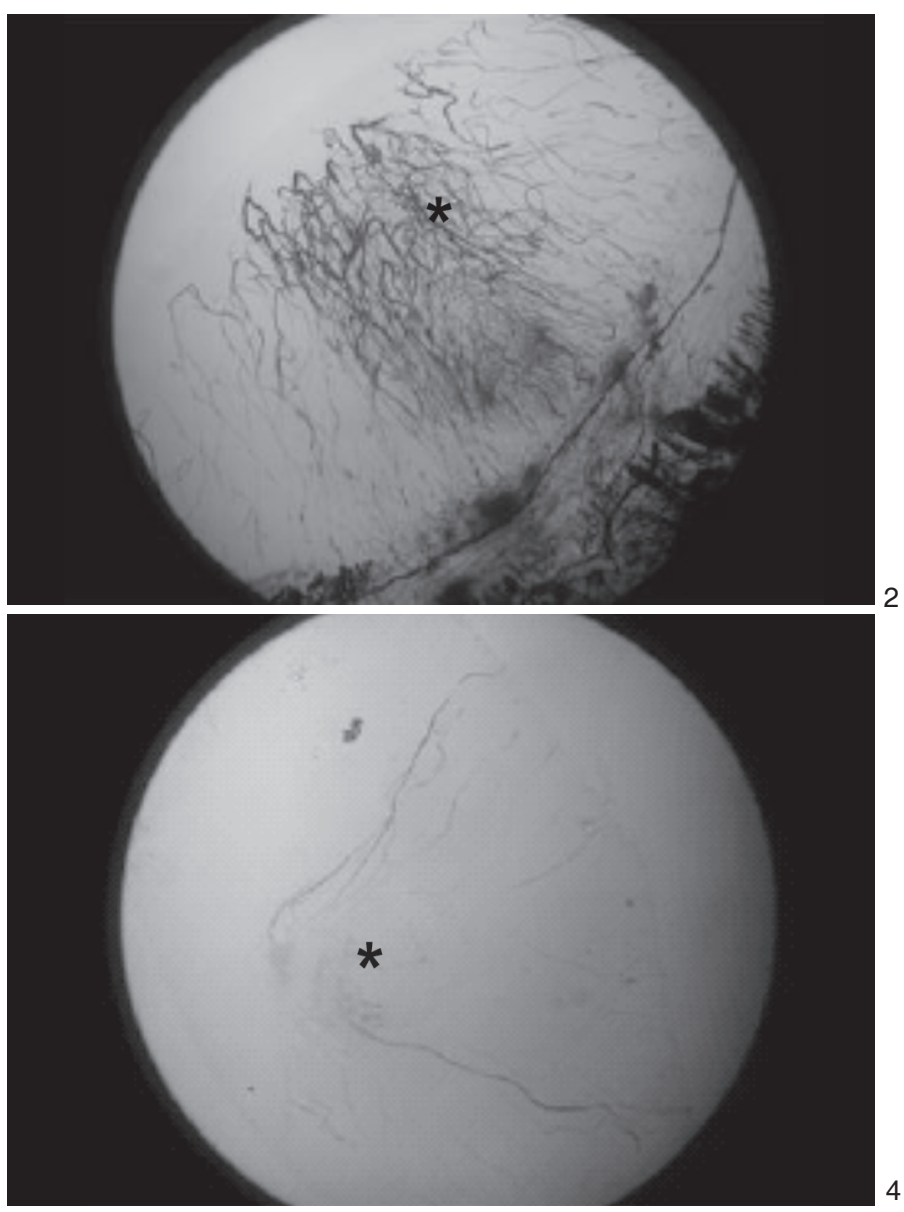

Fig.2. Rat cornea after intravenous injection of Nankeen Ink 15 days after the implantion of amniotic membrane and treatment with CsA. Observe smaller corneal neovascularization involving the amniotic membrane implant $(*)$, comparing with Figure 1.

Fig.4. Rat cornea after intravenous injection of Nankeen Ink 60 days after the implantation of amniotic membrane, with topical treatment with CSA. Note that the neovascularization is almost absent. ( $*=$ amniotic membrane implant) 
the $60^{\text {th }}$ day postoperatively was later observed (Fig.3, 4). Such analysis did not indicate that there was an individual difference in neovascularization between treated and untreated eyes.

\section{Statistical analysis}

Analysis of averages and their standard deviations indicated there was more obvious neovascularization the $3^{\text {rd }}$ day postoperatively and reaching its peak in treated and no treated groups on the $7^{\text {th }}$ day postoperatively. The neovascularization decreased rapidly until the $15^{\text {th }}$ day postoperatively, and then more regressed until the $60^{\text {th }}$ day postoperatively. Analysis of variances with repeated measures indicated that there was a significant difference in the interaction term $(p=0.0067)$, i.e., neovascularization densities vary in a different way between treated and untreated eyes in each period.

Bonferroni's and Tukey-Kramer's multiple comparisons between eyes found that the variation indicated in analysis of variance occurred on the $7^{\text {th }}$ day, and that treated eyes showed more neovascularization than untreated eyes.

Bonferroni's and Tukey-Kramer's multiple comparisons between periods were performed for both treated and untreated eyes, and indicated:

Treated eye. There was neovascularization equivalence among days 1, 3, 30 and 60 , which differed from days 7 and 15 , which are equivalent between themselves.

Untreated eye. There was neovascularization equivalence among days 1,3 and 60 , but not between day 30 , which was equivalent to day 15 . There was also equivalence between day 7 and 15 .

Therefore, statistical analysis found that the peak of neovascularization occurred on the $7^{\text {th }}$ day postoperatively, and that eyes treated with CsA had a larger peak than untreated eyes. However, on the $30^{\text {th }}$ day postoperatively,

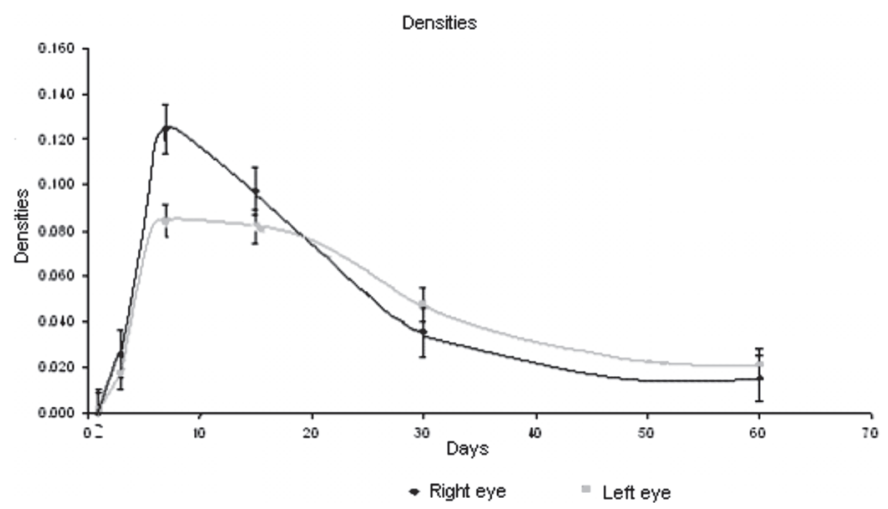

Fig.5. Averages and their respective standard errors of neovascularization densities obtained from corneas of eyes treated with CsA (right eye) and of untreated eyes (left eye) in the periods of $1,3,7,15,30$ and 60 days postoperatively. Through the image, it is observed a difference between the vascularization densities of the left and the right eye on day 7. After that, we observed that treated eyes had a quicker and more intense regression of neovascularization than untreated eyes. such a difference was inverted, and untreated eyes showed more neovascularization than treated eyes (Fig.5).

\section{Histopathologic analysis}

Histopathologic analysis indicated that on the $1^{\text {st }}$ day postoperatively there was intense inflammatory reaction at the limbus both in treated and in untreated eyes. On the $3^{\text {rd }}$ day, there was a small amount of neovascularization in the implant region. On the $7^{\text {th }}$ day, neovascularization became more obvious, and deposition of collagen in the implant begins. On the $15^{\text {th }}$ day, there was total deposition of collagen in the implant area (Fig.6, 7, 8). On the $30^{\text {th }}$ day, neovascularization displayed clear signs of regression and amniotic membrane becomes confounding with stroma, especially in eyes treated with CsA. On the $60^{\text {th }}$

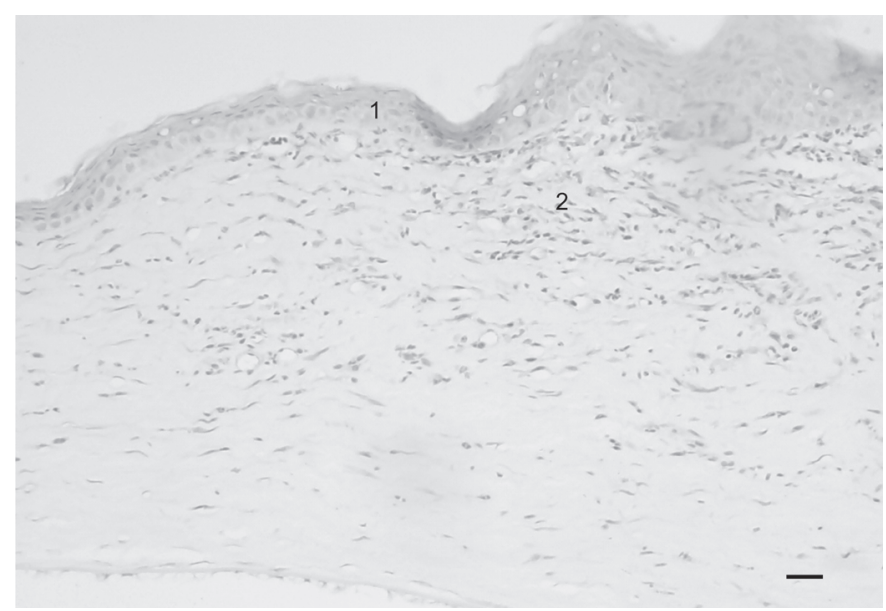

Fig.6. Rat cornea 15 days after amniotic membrane implant, without treatment, indicating epithelial regeneration (1), and fibroblastic proliferation in the implant area, with clear signs of deposition of collagen (2). HE, scale bar $=10 \mu \mathrm{m}$.

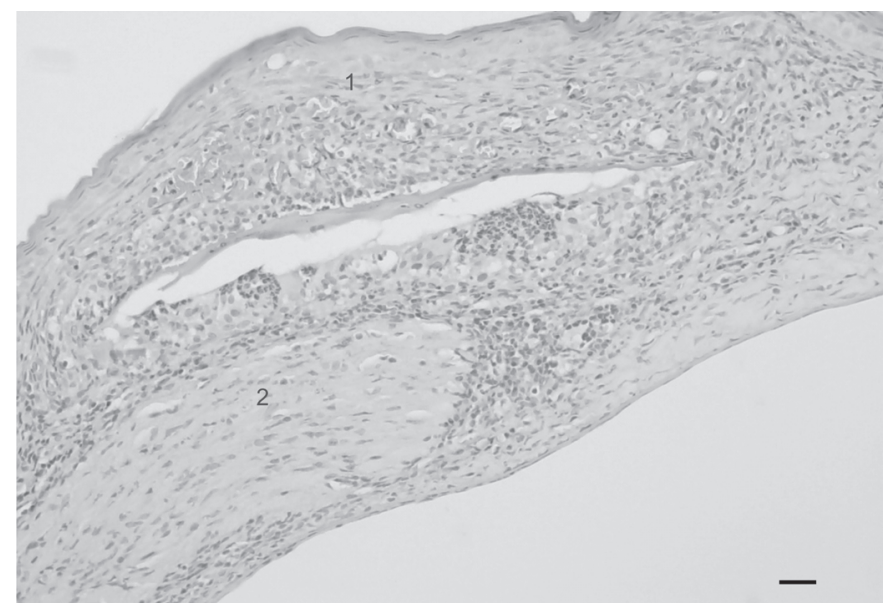

Fig.7. Rat cornea 15 days after amniotic membrane implantation and topical treatment with CsA, illustrating superficial epithelial regeneration in the implant area (1). In the underlying tissue an obvious cell proliferation intermixed with extracellular matrix can be observed (2). HE, scale bar = $10 \mu \mathrm{m}$. 


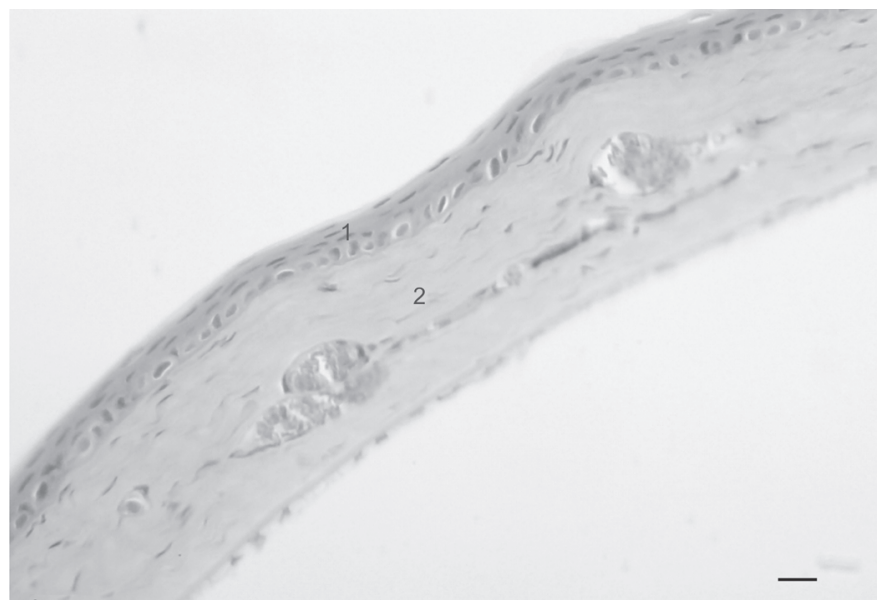

Fig.8. Rat cornea 60 days after amniotic membrane implantation without treatment, illustrating pluristratified epithelium (1) and an underlying area with dense connective tissue, in substitution of the implant tissue (2). HE, scale bar $=10 \mu \mathrm{m}$.

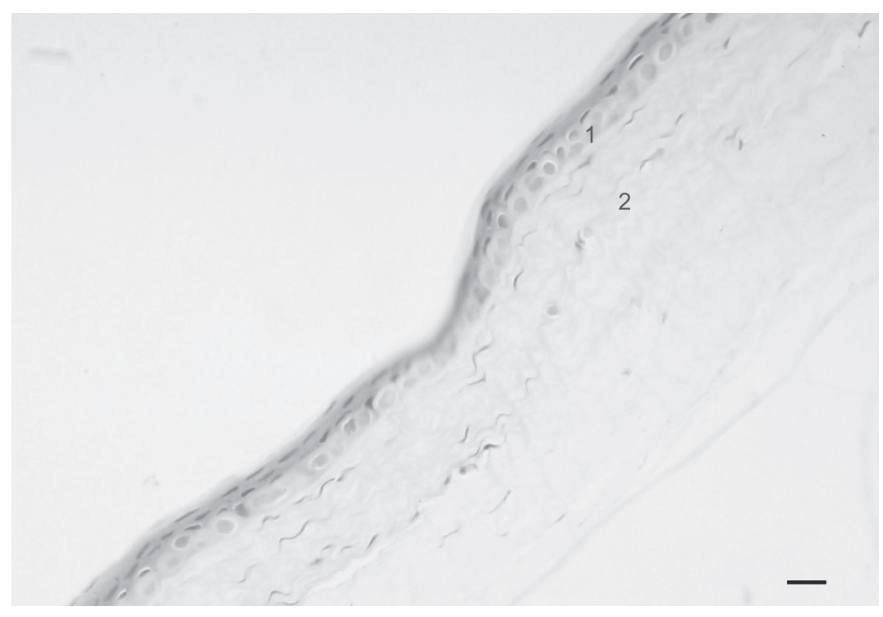

Fig.9. Rat cornea 60 days after amniotic membrane implantation after treatment with CsA, finding regenerated epithelium (1) and underlying area of implant with deposition of collagen (2). HE, scale bar $=10 \mu \mathrm{m}$.

day, the cornea is almost normal without neovascularization or signs of eyes implant (Fig.9).

\section{DISCUSSION}

Amniotic membrane has been widely used in ophthalmology for corneal repair, especially in cases with loss of the stroma tissue such as deep ulcerative keratitis, descemetocele, loss of cornea-sclera tissue after excision of neoplasias, symblepharon, eye burns, and pterygia among others (De Rotth 1940, Lee \& Tseng 1997, Shimazaki et al. 1997, Cheng et al. 2000, Chikamoto et al. 2001, Hanada et al. 2001, Solomon et al. 2001, 2002, Espana et al. 2002).

In veterinary medicine its utility has been growing. For instance, it has been already used to repair full-thickness defects of the cornea of dogs (Barros et al. 1998), generalized keratomalacia, ankyloblepharon, and after fibrous histiocytoma removal in two dogs and a cat (Barros et al. 2005), to reconstruct corneal surface after excision of corneolimbal squamous cell carcinomas in nine horses (Olliver et al. 2006), and to repair corneal ulceration and keratomalacia in three horses (Lassaline et al. 2005).

It has also been used in human patients with deficient production of limbal stem-cells, not solely for eye reconstruction, but also for the ex vivo culture of such cells (Tsai et al. 2000, Anderson et al. 2001, Meller et al. 2002, Pan et al. 2002, Ti et al. 2002).

The amniotic membrane is a thin tissue, semitransparent with a thick and continuous basal membrane, and an avascular stromal matrix (Van Herendael et al. 1978, Modesti et al. 1984). It has a great immunological advantage, since its cells do not express leukocyte antigens of class I, and has some immunoregulatory factors rendering it less susceptible to transplant rejection (Adinolfi et al. 1982). The main advantages of its use in the reconstruction of the eye surface include: viability of the amnion, convenience and facility of its use, and facility of forming a new epithelium with decreased inflammation, vascularization and eye secretion (Tseng 2001).

However, its use leads to corneal neovascularization which has an important role in reabsorbing the implanted amniotic membrane and in deposition of stromal collagen, besides being responsible for injured cornea's cicatrization (Rehany \& Waisman 1994, Gris et al. 2002). Notwithstanding, such neovascularization also leads to undesired effects, such as loss of corneal transparency with decreased visual acuity and intense inflammatory response, and with loss of the immunological advantage and possible rejection of the transplant tissue (Rehany \& Waisman 1994).

Cyclosporine $A$ is a cyclic polypeptide from fungus Tolypocladium inflatum Gans, and presents the ability to inhibit the activation and proliferation of T-helper lymphocytes by blocking the release of lymphokines (Diasio \& Lobuglio 1996). It has been systemically used since 1979 in preventing transplant and for immunological diseases (Calne et al. 1979). In ophthalmology, it is used specially for decreasing cases of rejection of corneal implant and transplant (Calatayud et al. 2001). Since its systemic use has a high cost and results in several collateral effects, and its topical use leads to concentration levels in corneal epithelium higher than when it is used systemically, ophthalmologists began to use eye drops or ointments for the application of cyclosporine (Ponn et al. 2001, Theng et al. 2002).

Our study indicated that amniotic membrane implant led to corneal neovascularization which reached its peak on the $7^{\text {th }}$ day postoperatively, with a slight decrease until the $15^{\text {th }}$ day and then total regression at 60 days. On the $15^{\text {th }}$ day at the implant site, the corneal epithelium regenerated, and deposition of collagen in the stromal implant site was total. Topical application of CsA twice a day led to an increase in neovascularization in the 
beginning of the treatment, with a quicker and more intense regression of neovascularization as of the $15^{\text {th }}$ day when comparing treated to untreated eyes.

While one study detected Beta Transforming Growth Factor (TGF-) in vascularized corneas, another study demonstrated that TGF- $b$ is related to the tridimensional structure of capillary structures "like" in vitro. (Cursiefen et al. 2000, Darland \& D Amore 2001). Since Cyclosporine stimulates the expression of TGF-b in humans, in vivo and in vitro, this may be one of the mechanisms that led to an increase in neovascularization at the beginning of the experiment ( 7 days postoperatively) (Suthanthiran \& Strom 1994, Khanna et al. 1997, Goodman et al. 2001, Stabellini et al. 2002).

One study evidenced that after a corneal injury, neovascularization process begins with a non-proliferative stage in the first 48 hours, followed by a proliferative stage with a high rate of vascular growth and, thereafter, with a regression stage with decrease in density of the new vessels (Edelman et al. 1999). It is hypothesized that in the first two stages there is an increase in expression of the Vascular Endothelium Growth Factor (VEGF), whilst in regression stage there is a decrease of VEGF, thus suggesting that the increase in expression of VEGF is important for inducing and maintaining the neovascularization in cornea, and that its decrease leads to a regression of neovascularization (Edelman et al. 1999). Another study demonstrated that VEGF needs activation of Nuclear Factor of Activated T-Cells (NFAT) for inducing the genetic expression of Cyclo-Oxygenase-2 (COX-2) in endothelium cells (Hernandez et al. 2001). Since CsA inhibits NFAT, the angiogenesis stimulated and maintained by VEGF also is inhibited by CsA (Chreiber \& Crabtree 1992, Erlanger 1992, Mascarell \& Truffa 2002). Therefore, we demonstrated the possible mechanism through which CsA stimulated regression of neovases in our study.

CsA also inhibits Interleucin-2 (IL-2) and InterferonGamma (INF-g) that are associated to activation of macrophages (Hingorani et al. 1999). Macrophages are directly related to the angiogenesis, liberating proteolytic enzymes responsible for the discontinuance of vascular stability (Auerbach \& Auerbach 1994). Hence, the use of CsA may inhibite the activation of macrophages and decrease the neovascularization by this mechanism. Therefore, the use of Cyclosporine may be indicated in the postoperative period for implant/transplant of amniotic membranes in cornea in a way to decrease neovascularization led by its initial stage.

Our study concluded that equine amniotic membrane in rat corneal stroma led to an intense neovascularization until the 15th postoperative day followed by later regression; collagen deposition of the implanted tissue was entirely achieved on the 15th postoperative day, and use of CsA was linked with increase in the corneal neovascularization at first, followed by a rapid and intense regression.

However, many other factors are involved in corneal neovascularization, as well as in cyclosporine's mecha- nism of action; so several studies in this area will still be necessary to elucidate the way Cyclosporine acts on transplant angiogenesis.

Acknowledgements.- This paper was presented to Faculdade de Medicina Veterinária e Zootecnia, Universidade de São Paulo, by Dr. Milani to obtain her MSc Degree. We would like to thank FAPESP for the financial support (Fellowship Dr.Milani, FAPESP 00/12157-1).

\section{REFERENCES}

Adinolfi M., Akle C.A., McColl I., Fensom A.H., Tansley L., Connolly P., Hsi B.L., Faulk W.P., Travers P. \& Bodmer W.F. 1982. Expression of HLA antigens, b2-microglobulins and enzymes by human amniotic epithelial cells. Nature 295:325-327.

Anderson D.F., Ellies P., Pires R.T.F. \& Tseng S.C.G. 2001. Amniotic membrane transplantation for partial limbal stem cell deficiency. Brit. J. Ophthalmol. 85(5):567-575.

Andrade A.L., Laus J.L., Figueiredo F. \& Batista C.M. 1999. The use of preserved equine renal capsule to repair lamellar corneal lesions in normal dogs. Vet. Ophthalmol. 2(2):79-82.

Auerbach W. \& Auerbach R. 1994. Angiogenesis inhibition: A review. Pharmacol. Therap. 63:265-311.

Barros L.F.M. \& Belfort Jr R. 2007. The effects of the subconjunctival injection of bevacizumab (Avastin $®$ ) on angiogenesis in the rat cornea. Annals Braz. Acad. Sci. 79:389-394.

Barros P.S.M., Garcia J.A., Laus J.L., Ferreira A.L. \& Salles Gomes T.L. 1998. The use of xenologous amniotic membrane to repair canine corneal perforation created by penetrating keratectomy. Vet. Ophthalmol. 1:119-123.

Barros P.S.M., Safatle A.M.V., Godoy C.A., Souza M.S.B., Barros L.F.M., Brooks D.E. 2005. Amniotic membrane transplantation for the reconstruction of the ocular surface in three cases. Vet. Ophthalmol. 8:189-192.

Barros P.S.M., Safatle A.M.V., Malerba T.A. \& Burnier Jr M. 1995. The surgical repair of the cornea of the dog using pericardium as a keratoprosthesis. Braz. J. Vet. Res. Anim. Sci. 32:251-255.

Benelli U., Ross J.R., Nardi M. \& Klintworth G.K. 1997. Corneal neovascularization induced by xenografts or chemical cauterization: Inhibition by Cyclosporin A. Invest. Ophthalmol. Visual Sci. 38(2):274-282.

Calatayud M., Guell J.L., Gris O., Puig J., Arrondo E. \& Huguet P. 2001. Ocular involvement in a case of systemic indeterminate cell histiocytosis: A case report. Cornea 20(7):769-771.

Calne R.Y., Rolles K., White D.J.G., Thiru S., Evans D.B., McMaster P., Dunn D.C., Craddock G.N., Henderson R.G., Aziz S. \& Lewis P. 1979. Cyclosporin $A$ initially as the only immunossuppressant in 34 recipients of cadaveric organs: 32 kidneys, two pancreases and two livers. Lancet 2:1033.

Cheng H.J., Pires R.T.F. \& Tseng S.C.G. 2000. Amniotic membrane transplantation for severe neurotrophic corneal ulcers. Brit. J. Ophthalmol. 84(8):826-833.

Chikamoto N., Murashige T., Chikama T.I. \& Nishida T. 2001. A case of acute alkali burns treated by conjunctival resection with amniotic membrane transplantation. Rinsho-Ganka 55(13):1957-1961.

Chreiber S.L. \& Crabtree G.R. 1992. The mechanism of action of cyclosporin A and FK506. Immunol. Today 13:136.

Coxon A., Bolon B., Estrada J., Kaufman S., Scully S., Rattan A., Duryea D., Hu Y.L., Rex K., Pacheco E., Van G., Zack D. \& Feige U. 2002. Inhibition of interleukin-1 but not tumor necrosis factor suppresses neovascularization in rat models of corneal angiogenesis and adjuvant arthritis. Arthritis and Rheumatism 46:2604-2612. 
Cursiefen C., Rummelt C. \& Kuchle M. 2000. Immunohistochemical localization of vascular endothelial growth factor, transforming growth factor alpha, and transforming growth factor beta1 in human corneas with neovascularization. Cornea 19(4):526-533.

Darland D.C. \& D'Amore P.A. 2001. TGF-beta is required for the formation of capillary-like structures in three-dimensional cocultures of 10T1/2 and endothelial cells. Angiogenesis 4(1):11-20.

De Rotth A. 1940. Plastic repair of conjunctival defects with fetal membranes. Arch. Ophthalmol. 23:522-525.

Diasio R.B. \& Lobuglio A.F. 1996. Immunomodulators: Immunossupressive agents and immunostimulants, p.1291-1304. In: Hardman J.G., Goodman Gilman A. \& Limbird D.E. (ed.), The Farmacological Basis of Therapeutics. 9th ed. Library of Congress Cataloging, New York.

Edelman J.L., Castro M.R. \& Wen Y. 1999. Correlation of VEGF expression by leukocytes with growth and regression of blood vessels in the rat cornea. Investig. Ophthalmol. Visual Sci. 40(6):1112-1123.

Erlanger B.F. 1992. Do we know the site of action of cyclosporin? Immunol. Today 13:487.

Espana E.M., Prabhasawat P., Grueterich M., Solomon A. \& Tseng S.C.G. 2002. Amniotic membrane transplantation for reconstruction after excision of large ocular surface neoplasias. Brit. J. Ophthalmol. 86(6):640-645.

Godoy C.A.L, Guerra J.L. \& Barros P.S.M. 2002. Lamellar keratoplasty in dogs using equine fetal membrane as graft: Experimental study. Arqs Bras. Oftalmol. 65:545-549.

Goodman G.R., Dissanayake I.R., Bowman A.R., Pun S., Ma Y., Jee W.S.S., Bryer H.P. \& Epstein S. 2001. Transforming growth factorbeta administration modifies cyclosporine A-induced bone loss. Bone 28(6):583-588.

Gris O., Wolley D.C., Guell J.L., Tresserra F., Lerma E., Corcostegui B. \& Adan A. 2002. Histologic findings after amniotic membrane graft in the human cornea. Ophthalmology 109(3):508-512.

Hakanson N.E. \& Merideth R.E. 1986. Conjunctival pedicle grafting in the treatment of corneal ulcers in the dog and cat. J. Am. Anim. Hospital Assoc. 23:641-648.

Hanada K., Shimazaki J., Shimmura S. \& Tsubota K. 2001. Multilayered amniotic membrane transplantation for severe ulceration of the cornea and sclera. Am. J. Ophthalmol. 131(3):324-331.

Heier J.S., Antoszyk A.N., Pavan P.R., Leff S.R., Rosenfeld P.J., Ciulla T.A., Dreyer R.F., Gentile R.C., Sy J.P., Hantsbarger G. \& Shams N. 2006. Ranibizumab for treatment of neovascular age-related macular degeneration. Ophthalmology 113:633-642e4.

Hernandez G.L., Volpert O.V, Iniguez M.A., Lorenzo E., Martinez M.S., Grau R., Fresno M. \& Redondo J.M. 2001. Selective inhibition of vascular endothelial growth factor-mediated angiogenesis by cyclosporin A: Roles of the nuclear factor of activated T cells and cyclooxygenase 2. J. Exp. Med. 193(5):607-620.

Hingorani M., Calder V.L., Buckley T.J. \& Lightman S. 1999. The immunomodulatory effect of topical cyclosporin A in atopic keratoconjunctivitis. Investig. Ophthalmol. Visual Sci. 40(2):392-399.

Hosseini H. \& Nejabat M.A. 2007. Potential therapeutic strategy for inhibition of corneal neovascularization with new anti-VEGF agents. Medical Hypotheses 68:799-801.

Khanna A., Kapur S., Sharma V., Li B. \& Suthanthiran M. 1997. In vivo hyperexpression of transforming growth factor-beta 1 in mice: stimulation by cyclosporine. Transplantation 63:1037-1039.

Kwon Y.S. \& Kim J.C. 2006. Inhibition of corneal neovascularization by rapamycin. Exp. Molecul. Med. 38:173-179.

Lassaline M.E., Brooks D.E., Ollivier F.J., Komaromy A.M., Kallberg M.E. \& Gelatt K.N. 2005. Equine amniotic membrane transplantation for corneal ulceration and keratomalacia in three horses. Vet. Ophthalmol. 8:311-317.
Lavie G., Mandel M., Hazan S., Barliya T., Blank M., Grunbaum A., Meruelo D. \& Solomon A. 2005. Anti-angiogenic activities of hypericin in vivo: potential for ophthalmologic applications. Angiogenesis 8:3542.

Lee S.H. \& Tseng S.C.G. 1997. Amniotic membrane transplantation for persistent epithelial defects with ulceration. Am. J. Ophthalmol. 123:303-312.

Liu Y., Cao J., Renard R.A., Song H., Hylton H., Rudge J.S., Papadopoulos N., Yancopoulos G.D. \& Wiegand S.J. 2006. Low dose, subconjuntival administration of VEGF trap inhibits suture-induced corneal neovascularization and inflammation. Proc. ARVO Annu. Meet., Fort Lauderdale, USA, p.1626.

Macugem Diabetic Retinopathy Study Group. 2006. Changes in retinal neovascularization after pegaptanib (Macugen) therapy in diabetic individuals. Ophthalmology 113:23-28.

Manzano R., Peyman G., Khan P., Carvounis P., Kivilcim M., Ren M., Lake J. \& Chevez-Barrios P. 2006. Inhibition of experimental corneal neovascularization by Bevacizumab (AVASTIN). Brit. J. Ophthalmol. 91:804-807.

Mascarell L. \& Truffa B.P. 2002. Cyclosporin A therapy differently affects immunological-relevant gene expression following immunization. Immunol. Letters 84(2):137-143.

Meller D., Pires R.T.F. \& Tseng S.C.G. 2002. Ex vivo preservation and expansion of human limbal epithelial stem cells on amniotic membrane cultures. Brit. J. Ophthalmol. 86(4):463-471.

Modesti A., Kalebic T., Scarpa S., Togo S., Grotendorst G., Liotta L.A. \& Triche T.J. 1984. Type V collagen in human amnion is a 12-nm fibrillar component of the pericellular interstitium. Eur. J. Cell Biol. 35:246-255.

Ollivier F.J., Kallberg M.E., Plummer C.E., Barrie K.P., O'Reilly S.O., Taylor D.P., Gelatt K.N. \& Brooks D.E. 2006. Amniotic membrane transplantation for corneal surface reconstruction after excision of corneolimbal squamous cell carcinomas in nine horses. Vet. Ophthalmol. 9:404-413.

Pan Z., Zhang W. \& Wu Y. 2002. Transplantation of corneal stem cells cultured on amniotic membrane for corneal burn. Chinese Med. J. 115(5):767-769. (English edition)

Ponn A.C., Forbes J.E., Dart J.K.G., Subramaniam S., Bunce C., Madison P., Ficker L.A., Tuft S.J., Gartry D.S. \& Buckey R.J. 2001. Systemic cyclosporin $A$ in high risk penetrating keratoplasties: A case-control study. Brit. J. Ophthalmol. 85(12):1464-1469.

Rehany U. \& Waisman M. 1994. Suppression of corneal allograft rejection by systemic Cyclosporine-A in heavily vascularized rabbit corneas following alkali burns. Cornea 13(5):447-453.

Riazi-Esfahani M., Peyman G.A., Aydin E., Kazi A.A., Kivilcim M. \& Sanders D.R. 2006. Prevention of corneal neovascularization: evaluation of various commercially available compounds in an experimental rat model. Cornea 25:801-805.

Safatle A.M.V., Barros P.S.M., Malucelli B.E. \& Guerra J.L. 2002. Implantation of two biological membranes in a corneal micropocket as an experimental model for angiogenesis. Braz. J. Vet. Res. Anim. Sci. 39(4):189-195.

Shimazaki J., Yang H.Y. \& Tsubota K. 1997. Amniotic membrane transplantation for ocular surface reconstruction in patients with chemical and thermal burns. Ophthalmology 104(12):2068-2076.

Solomon A., Meller D., Prabhasawat P., John T., Espana E.M., Steuhl K.P. \& Tseng S.C.G. 2002. Amniotic membrane graft for nontraumatic corneal perforations, descemetoceles, and deep ulcers. Ophthalmology 109(4):691-703.

Solomon A., Pires R.T.F. \& Tseng S.C.G. 2001. Amniotic membrane transplantation after extensive removal of primary and recurrent pterygia. Ophthalmology 108(3):449-460.

Stabellini G., Carinci F., Bedani P.L., Calastrini C., DeMattei M., Scapoli L., Caruso A., Calvitti M. \& Locci P. 2002. Cyclosporin A and 
transforming growth factor beta modify the pattern of extracelular glycosaminoglycans without causing cytoskeletal changes in human gingival fibroblasts. Transplantation, Baltimore, 73(10):16761679.

Suthanthiran M. \& Strom T.B. 1994. Renal transplantation. New Engl. J. Med. 331:365-376.

Theng J., Zhou L., Tan D. \& Lam K.W. 2002. Distribution of cyclosporin A in the cornea after topical or oral administration. J. Ocular Pharmacol. Therap. 18(1):83-88.

Ti S.E., Anderson D., Touhami A., Kim C. \& Tseng S.C.G. 2002. Factors affecting outcome following transplantation of ex vivo expanded limbal epithelium on amniotic membrane for total limbal deficiency in rabbits. Invest. Ophthalmol. Visual Sci. 43(8):2584-2592.

Tsai R.J.F., Li L.M. \& Chen J.K. 2000. Reconstruction of damaged corneas by transplantation of autologous limbal epithelial cells. New Engl. J. Med. 343(2):86-93.

Tseng S.C.G. 2001. Amniotic membrane transplantation for ocular surface reconstruction. Bioscience Reports 21(4):481-489.

Van Herendael B.J., Oberti C. \& Brosens I. 1978. Microanatomy of the human amniotic membranes. A light microscopic, transmission, and scanning electron microscopic study. Am. J. Obstet. Gynecol. 131:872880. 